\title{
Studies on Virulence Genes of Staphylococcus Aureus Isolated from Mastitic Cows
}

\author{
A.A.Abd El-Tawab ${ }^{1}$, A.M.Ammar ${ }^{2}$, F.I.Hofy ${ }^{1}$, S.R.Mohamed ${ }^{3}$, H.S.Abubakr ${ }^{3}$ \\ ${ }^{1}$ Bacteriology, Immunology and Mycology Dept., Faculty of Veterinary Medicine, Benha Univ., Benha, Egypt \\ ${ }^{2}$ Bacteriology,Immunology and Mycology Dept., Faculty of Veterinary Medicine, Benha Univ., Benha, Egypt \\ ${ }^{3}$ Animal Health Research Institute(Dokki branch) \\ E-Mail: halahhableen@gmail.com
}

\begin{abstract}
Staphylococcus aureus is the most frequently bacterial pathogen causing clinical and subclinical mastitis in cattle. In this research the mastitic cases (103) were classified into clinical and subclinical cases ..(47,56) respectively.

All milk samples collected from infected cows were subjected to bacteriological examination and molecular characterization of some Staphylococcus aureus isolates. Staphylococcus aureus was isolated from clinical and subclinical mastitic cows in an incidence of $(50 \%, 17 \%)$ respectively .

The application of multiplex PCR on some Staph.aureus isolates (8) was effectively in detection of Coa. SpA, ,TST,HIg, CLF, nucgenes by amplification at a single amplicon at (630bp, 226 bp,326bp, 937bp, 638bp, 395 bp respectively).
\end{abstract}

Keywords: S.aureus, cows, mastitis, Pcr, virulence genes.

\section{Introduction}

Milk is considered as an excellent medium for growing of many microorganisms. Milk can be contaminated with several bacteria during milking process from the milking personnel, utensils used for milking [1].

Mastitis is recognized as the most important dairy herd problems worldwide .Economic losses of mastitis include decrease in milk quantity and quality and high cost treatment. S.aureus is one of the most common etiological pathogens, causing intrammamry infections in dairy herds leading to serve economic losses in worldwide industry [2].

The main reservoir of S.aureus seems to be the infected quarter, and transmission between cows usually occurs during milking. S.aureus produces a spectrum of extra cellular protein toxins and virulence factors which are thought to contribute to the pathogenicity of the organism [3] while TST-1 is a superantigenic exotoxin that causes toxic shock syndrome[4]

The coa gene is one of the most important virulence factors for S.aureus Expression of this gene is thought to enhance bacterial growth and promote infection in the face of the host defense mechanisms, such as phagocytosis [5]

Pathogenesis of mastitis may be caused by extracellular toxins, enzymes and surface antigens [6]. Coagulase gene of $S$. aureus is considered an important virulence factor. Amplification of $S$. aureus coagulase gene (coa) has been recommended as an accurate method for identification of virulent strains of $S$. aureus [7] Sequencing of the coagulase gene shows great diversity in $S$. aureus population [8].

This study aimed to throw the light on the incidence of staphylococcus aureus in clinical and subclinical mastitis, the genotypic characterization of some $S$. aureus strains isolated from dairy cows suffering from mastitis and provided an overview on the distribution of virulence determinants of these $S$. aureus strains which contribute in bovine mastitis problem in the Egyptian farms .

\section{Material \& methods}

1. Samples

A total of 412 milk samples were collected from clinically and sub clinically infected cases the samples were transferred in ice box directly with an hour to the laboratory with a minimum delay to be bacteriologically examined[9].

\section{Bacteriological examination}

All samples were inoculated onto blood agar base (Merck) supplemented with 5\%defibrinated sheep blood and mannitol salt agar plates and incubated aerobically at $37 \mathrm{C}^{\circ}$ for $24 \mathrm{~h}$ Suspected colonies were picked up for purification and subjected for identification microscopically and biochemically according to $[10,9,11,12]$ isolates were identified by conventional methods, including Gram staining, colony morphology, hemolysis test, catalase, coagulase and anaerobic fermentation of mannitol [13].

\section{Detection of virulence genes of Staphylococcus aureus by PCR}

Primers for detection of 6virulence gene of Staphylococcus aureus, these genes were Spa , $h l y A, c o a, t s t, n u c$ and $c l f A$. It was applied on 8 random isolates of Staphylococcus aureus following QIAamp® DNA Mini kit instructions (catalogue no. M501DP100), Emerald Amp GT PCR mastermix (Takara) with code NO. rr310A and agarose gel electrophoreses [14] sequence of primer used are illustrated in Table (1) 


\section{Results}

Detection of virulence genes of S.aureus isolated from mastitic cattle

spa gene (protein A ) amplified at 226bp were 5 positive, 3 negative in an incidence of $(62.2 \%)$ and (37.5\%) respectively as shown in Fig (1)

Nuc gene (Thermonuclease )amplified at 395bp were 3 positive and 5 negative in an incidence of $(37.5 \%)$ and $(62.2 \%)$ respectively also TST gene (Toxic shock syndrome gene) amplified at $326 \mathrm{pb}$ were 2 positive and 6 negative as $(25 \%)$ and $(75 \%)$ respectively as shown in Fig (2), Coa gene (Coagulase gene) amplified at 630 bp were 4 positive , 4 negative as (50\%) and (50\%) in Fig (3)

CLF gene (clumbing factor) amplified at $638 \mathrm{bp}$ where 3 were positive 5 negative in an incidence of $(37.7 \%)$ and $(62.6 \%)$ respectively as shown in Fig (4) also HI gene hemolysin gene amplified at 937 bp where 4 were positive and 4 negative $\mathrm{HI}$ gene positive were $(50 \% \mid)$ and negative were $(50 \%)$.

\section{Discussion}

Several virulence factors were produced by $S$. aureus including Coagulase protein which encoded by $\mathrm{Coa}$ gene which is important in the pathogenicity [15]. Through turn fibrinogen to fibrin which lead to abscessiation and persistence of microorganism in host tissue. Furthermore the detection of Coagulase is considered to be virulence factor in intrammmary infection. Coagulase gene can be used as a simple and effective method for typing of $S$. aureus isolates from bovine mastitis . [16]. In this study Coa gene was detected in five isolates $(62.5 \%)$ and give a single Amplicon of 630 bp as shown in fig (3). This seem to be agree with [17] who recorded a single amplicon of Coa genes at $600 \mathrm{bp}$ of Staphylococcus aureus isolated from bovine mastitis. Moreover the findings reported by[18] suggesting that the amplicon of about 600 bp are predominant in bovine strains. Epidemiological studies indicates that $S$. aureus strains agents of mastitis produce a group of virulence factor and its believed that there is a relationship between severity of mastitis and the virulence factors produced by Staphylococcus aureus. Presence of clfA and hla gene Fig (4) and protein A considered as the staphylococcus species.

Amplification of clumbing factor $\mathrm{A}(\mathrm{clf} A)$ gene resulted in a single amplicon with a size of approximately 638bp for all (8)S. aureus strains indicating no size polymorphisms of this gene (clfA) - Amplification of Saureus protein A gene spa resulted in a single amplicon with a size of approximately $226 \mathrm{bp}$ for $9 \mathrm{~S}$. aureus out of 10 (90\%)our results revealed that (5)isolates out of (8) tested $(62.5 \%)$ have coa gene. Moreover coagulase gene tend to have different PCR products indicating the polymorphism of Coa gene. Staphylococcus aureus protein A (Spa) (Fig. 1) which encoded by the spa gene is a major important surface proteins of bacterial cell wall product which binds with FC region of immunoglobulin $G$ and impairs the opsonisation of serum complement and phagocytosis by polymorpho nuclear leukocytes of the host immune system, so the decrease in spa on cell surface of $S$. aureus resulted in increasing number of free receptor sites for complement $\mathrm{C} 3 \mathrm{~b}$ and phagocytosis [19].In this study amplification of spa gene of Staphylococcus aureus was detected at $229 \mathrm{bp}$ in 6 isolates $(75 \%)$, all 8 tested strain $(32.6 \%)$ were positive for Spa gene Fig (1).[20] achieved that spa gene can be used for typing the isolates of S.aureus. The detection of genetic polymorphisms in the $\mathrm{X}$ region of the spa gene can be used for typing of $S$. aureus. [19]. Also [21]concluded that detection of spa gene polymorphisms with coa-PCR proposed as good diagnostic methods for typing of Staphylococcus aureus isolates which provide important results for the assessment of effective strategies against staphylococcal mastitis control.

In addition, some reports suggested that $S$. aureus strains that express SEC and TSST-1 in combination cause severe clinical mastitis that is unresponsive to treatment

The present study showed heterogeneity in the coa gene of $S$. aureus strains. In Pakistan similar findings were reported by [22,3]. Less variation in coa gene of $S$. aureus was found in the present study, which agrees with[23] The PCR amplicons variation in size of coagulase gene could be due to polymorphism among different isolates obtained from different herds and previous studies have also confirmed PCR product variation using molecular analysis of the coagulase gene [22].

S.aureus is recognized worldwide as frequent cause of intramammary infections in dairy cows. The main reservoir of $\mathrm{S}$. aureus seems to be the infected quarter, and transmission between cows usually occurs during milking. S. aureus produces a spectrum of extracellular protein toxins and virulence factors which are thought to contribute to the pathogenicity of the organism [24].

The ability of $S$. aureus to adhere to extracellular matrix proteins is thought to be essential for the colonization and the establishment of infections [25].S.aureus possesses various adhesion genes, including $c l f A$, fnbA [26].PCR analyses of $c l f A$ genes Fig (4) in the investigated 8 strains suggesting an important role of these elements in the pathogenicity of bovine mastitis. However,[27] found that some genes including clfA and $S$. aureus protein A gene spa were present in both antimicrobial resistant and susceptible isolates, statistical analysis showed there is a strong relationship with resistance patterns.

Amplification of genes encoding clumping factor (clfA) and thermonuclease(nuc) gene by polymerase chain reaction was used for the genotypic characterization of isolated $S$. aureus strains. Amplification of the clumping factor (clfA) gene 
resulted in a single amplicon with a size of approximately 638 bpfor all 8 tested $S$. aureus strains isolated from raw milk samples indicating no size polymorphisms of this gene. While the amplification of the nuc gene Fig (2). Produced an amplicon of 395 bp in all 8 examined $S$. aureus isolated from raw milk samples . Specificity of the PCR products was demonstrated with $100 \%$ of the tested isolates .This specificity of $S$. aureuswas agreed to the results recorded by[28] and [21].

Table (1) The results of PCR amplification of tested $S$. aureus isolates (8)

\begin{tabular}{llccc}
\hline \multicolumn{2}{l}{ Tested genes } & positive & Negative \\
\hline & No & $\%$ & no & \% \\
\hline Spa 5 & 62.2 & 3 & 37.5 \\
Nuc 3 & 37.5 & 5 & 62.2 \\
Tst 2 & 25 & 6 & 75 \\
Coa 4 & 50 & 4 & 50 \\
Hlg 4 & 50 & 4 & 50 \\
Clfa 3 & 37.5 & 5 & 62.2 \\
\hline
\end{tabular}

Percentage were calculated according to the no. of tested $S$. aureus isolates (8)

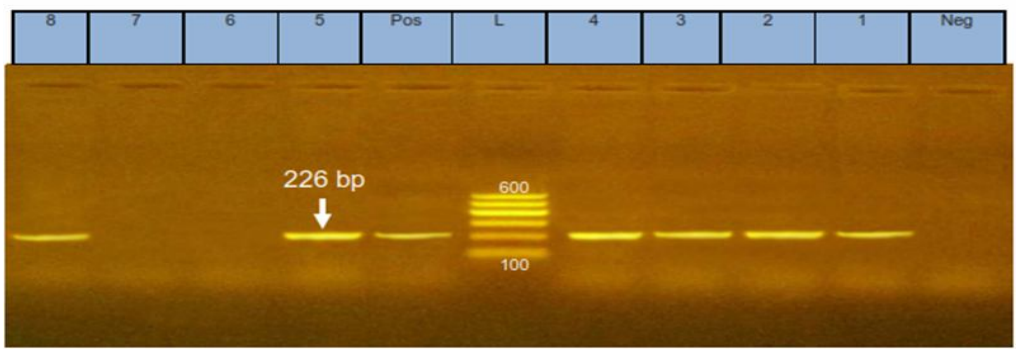

Fig (1) SPA gene. Lane M: 100-600 pb DNA ladder. Neg: Negative control. Pos: positive control 226bp.Lane: 1,2,3,4,8 pos. Lane: 6,7 Neg

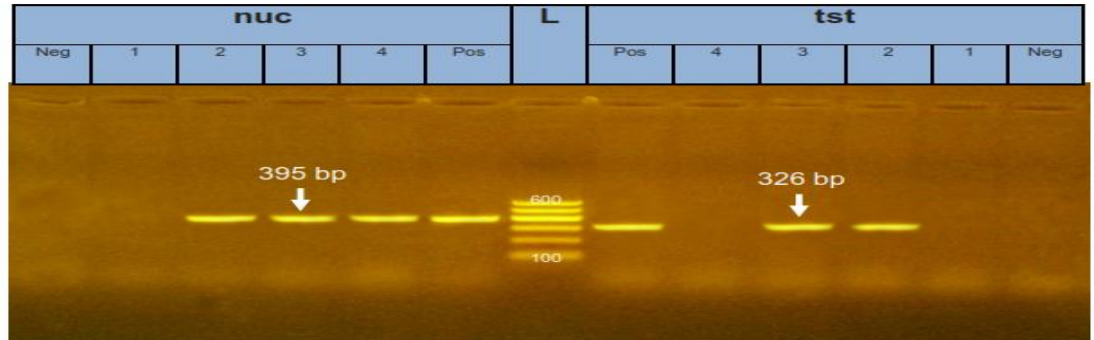

Fig (2) NUC gene. Lane M: 100-600 pb DNA ladder. Neg: Negative control. Pos: positive control 630bp.Lane: 2,3,4, pos. Lane: 1 Neg.TST gene Lane M: 100600 pb DNA ladder. Neg: Negative control. Pos: positive control 326pb.Lane: 2,3 pos. Lane: $1,4 \mathrm{Neg}$

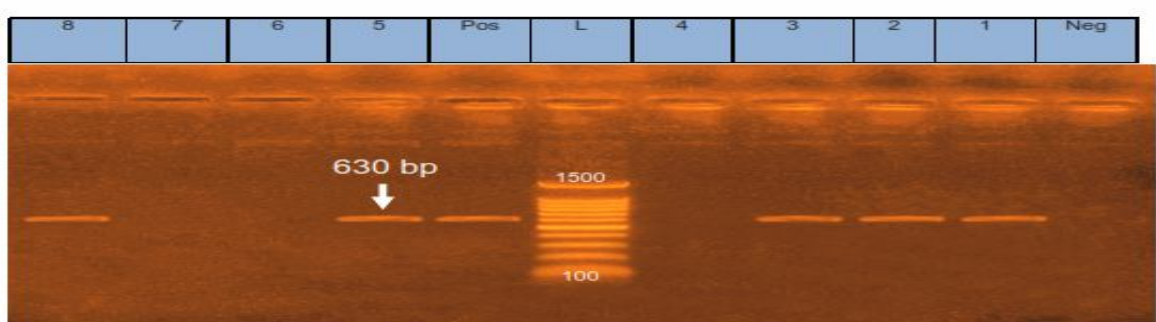

Fig (3) Co a gene. Lane M: 100-1500 pb DNA ladder .Neg: Negative control. Pos: positive control 630bp.Lane: $1,2,3,8$ pos. Lane: $4,6,7, \mathrm{Neg}$ 


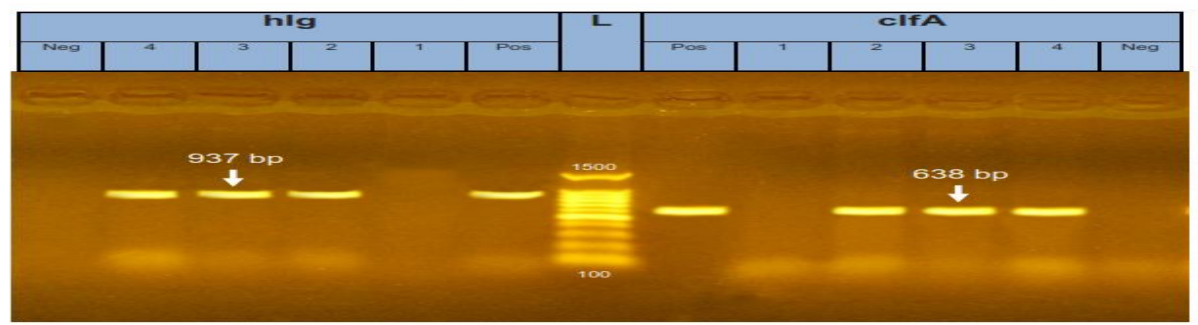

Fig (4) CLFA gene. Lane M: 100-1500 pb DNA ladder.

Neg: Negative control. Pos: positive control 638bp.Lane: 2,3,4 pos. Lane: 1 Neg. Hlg gene. Lane M: 100-1500 pb DNA ladder. Neg: Negative control. Pos: positive control 937bp.Lane: 2,3,4 8 pos. Lane: $1 \mathrm{Neg}$

\section{Conclusion}

Data presented in this study showed that a broad distribution of identical or closely related $S$. aureus clones are responsible for the mastitis situation in, Egypt. Due to $S$. aureus isolates from cows with bovine mastitis were found to differ in their gene patterns, genotypic characterization provided a better understanding of the distribution of the prevalent $S$. aureus clones among bovine mastitis isolates. This can aid in the investigation and control of $S$. aureus infections in dairy herds. Further studies aim to obtain more data about different species will be conducted indifferent regions in Egypt.

\section{References}

[1] M.U.Rehman, M.Rashid , J.A.Sheikh, M.A.Bhat Molecular epidemiology and antibiotic resistance pattern of enteropathogenic Escherichiacoli isolated from bovines and their handlers in Jammu, India. Journal of Advanced Veterinary and Animal Research, vol.1, pp.177$181,2014$.

[2] R.G.,OldeRiekerink,H.WBarekma, D.T., Scholl, D.E.Poole, D.F Kelton management practices associated with bulk-milk prevalence of S.aureus in Canadian dairy farms. Prev.Vet.Med., vol.97(1), pp.20-28, 2010.

[3] H.Momtaz, E.Rahimi, E.Tajbakhsh, Detection of some virulence factors in Staphylococcus aureus isolated from clinical and subclinical bovine mastitis in Iran. AfricanJ.of Biotechnology, vol.9(25), pp.3753-3758, 2010.

[4]J.M.Fueyo, M.C.Mendoza, M.C.Martin, Enterotoxins and toxic shock syndrome toxin in Staphylococcus aureus recovered from human nasal carriers and manually handled foods: Epidemiological and genetic findings. Microbes Infect. Vol.7, pp.187-194, 2005.

[5] F.M.Aarestrup, C.A.Dangler, L.M. Sordillo Prevalence of coagulase gene polymorphism in Staphylococcus aureusisolates causing bovine mastitis. Can J Vet Res vol.59, pp.124$128,1995$.

[6] K.O'Riordan, and J.C.Lee Staphylococcus aureus capsular polysaccharides. Clin. Microbiol. Rev., vol.17, pp.218-234,2004.
[7] S.Morandi, M.Brasca, R.Lodi, L.Brusetti, C.Andrighetto and A.Lombardi Biochemical profiles, restriction fragment length polymorphism (RFLP), random amplified polymorphic DNA (RAPD) and multilocus variable number tandem repeat analysis (MLVA) for typing Staphylococcus aureusisolated from dairy products. Res. Vet. Sci., vol.88, pp.427-435, 2010.

[8] G.M.Costa, L.V.Paiva, H.C.P.Figueiredo, A.R.Figueira, U.P.Pereira and N.Silva Population diversity of Staphylococcus aureus isolated from bovine mastitis in Brazilian dairy herds. Res. Vet. Sci., vol.93, pp.733-735, 2012.

[9] P.J.Quinn, B.K.Makey, M.E.Carter, W.J.Donnelly and F.C.Leonard, Veterinary Microbiology and Microbial Diseases. Blackwell Science Ltd, 2002.

[10] J.G.Collee, A.G.Fraser, B.P.Marmion and A.Stilmmow, Practical medical microbiology. 14th Ed. Churchill, Livingstone, New York, 1996.

[11] P.Boerlin, P.Kuhnert, D.Hussy and M. Schaellibaum, Methods for identification of S. aureus in cases of bovine mastitis. J. Clin. Microbiol, vol.41(2), pp.767-777, 2003.

[12] F.De FreitasGuimaraes, D.B.Nobrega, V.B.Richini- Pereira, P.M.Marson, J.C.FigueiredoPantoja, and H.Langoni,. .Enterotoxin genes in coagulase- negative and coagulase-positive staphylococci isolated from bovine milk. J. Dairy Sci, vol.96, pp.2866-2872, 2013.

[13] E.W.Koneman, S.D.Allen, W.M.Janda, P.C.Schrechenberger and W.C Winn, colour Atlas and textbook of diagnostic microbiology (Fourth edition), 1979, 1983, 1988, 1992 by J. B. Lippincott Company, 1992.

[14] J.Sambrook, E.F.Fritscgh and Mentiates Molecular coloning. A laboratory manual. Vol, Cold spring Harbor Laboratotry press, New York, 1989.

[15] HassanMomtaz \& ElaheTajbakhsh \& EbrahimRahimi\& Manochehr MomeniCoagulase gene polymorphism of Staphylococcus aureus isolated from clinical and sub-clinical bovine mastitis in Isfahan and 
Chaharma halva Bakhtiari provinces of Iran Comp ClinPathol vol.20, pp.519-522, 2011.

[16] M.Mcadow, H.K.Kim, A.C.Dedent, A.P.Hendrickx, O.Schneewind and M.Missiakas, Preventing Staphylococcus aureus sepsis through the inhibition of its agglutination in blood, PLoSPathog. 7, e1002307, 2011.

[17] M.E.Enany, S.Younes, A.M.AL-gammal , Salem and H.A.El Dieb, Prevalence of coagulase (coa) gene and mec A gene of S. aureus isolated from bovine clinical mastitis . Seuz Canal Veterinary Medicine Journal, vol.XVIII (1), pp.147-157, 2013.

[18] K.G.Carbal, C.Lammler, M.Zschoc, H.Langoni, De Sa Me, C.Victoria andA. Da Silva , Pheno - and genotyping of Staphylococcus aureus, isolated from bovine milk samples from Sao Paulo State, Brazil. Can. J. Microbiol, vol.50(11), pp.901-9092, 2004.

[19] J.Gao and G.C.Stewart Regulatory elements of the Staphylococcus aureus protein A (Spa) promoter. J.Bacteriol, vol.186, pp.3738-3748, 2004.

[20] S.Mohammed, M.Abdelrahman and D.Abdulla ,(Phenotypic and genotypic detection of virulence factors of staphylococcus aureus isolated from clinical and subclinical mastitis in cattle Veterinary World J., pp.2231-0916, 2015.

[21] M.Karahan , M.N.Acik and B.Cetinkaya, B.Investigation of virulence genes by PCR in Staphylococcus aureus isolates originated from subclinical bovine mastitis in Turkey. Pak Vet J, vol.31(3), pp.249-253, 2011.

[22] A.Khan, R.Hussain, M.T.Javed and F.Mahmood, Molecular analysis of virulent genes (coa and spa) of Staphylococcus aureus involved in natural cases of bovine mastitis. Pakistan. J. Agri. Sci, vol.50, pp.739-743, 2013.

[23] T.Mork, T.Tollersrud, B.Kvitle, J. Jorgensen and S.Waage Comparison of Staphylococcus aureus genotypes recovered from cases of bovine, ovine, and caprine mastitis. J.Clin. Microbiol, vol.43, pp.3979-3984, 2005.

[24] M.M.Salem-Bekhit, M.M.Muharram, , I.M.Alhosiny.M and E.S.Y.Hashim. Molecular Detection of Genes Encoding Virulence Determinants in Staphylococcus aureus Strains isolated from Bovine Mastitis Journal of Applied Sciences Research,vol.6(2), pp.121$128,2010$.

[25] SI.Salasia , Z.Khusnan, R.C.Lamme and M.Zschock Comparative studies on pheno and genotypic properties of Staphylococcus aureusisolated from bovine subclinical mastitis in central Java in Indonesia and Hesse in Germany. J. Vet. Sci. vol.5, pp.103-109, 2004.

[26] El-Sayed, A.Alber, J.C.Lammler, B.Bonner, A.Huhn, E.F.Kaleta and M.Zschock ..PCR based detection of genes B. Infect. Dis. Vet Public Health, vol.52, pp.38-44, 2005.

[27] T.Brody, A.S.Yavatkar, Y.Lin, J.Ross, AKuzin, M.Kundu., Y.Fann, andW.F. Odenwald.Horizontal gene transfers link a human MRSA pathogen to contagious bovine mastitis bacteria. PLOS ONE, vol.3, pp.3074, 2008.

[28] A.Ozkan ,D.Cemil, T.Hulya, C.Zafer, E.Yaflar and D.Gokhan .Coagulase gene polymorphism of Staphylococcus aureus isolated from subclinical mastitis .Turk.J.Vet. Anim.Sci.,vol.31(4), pp.253-257, 2007. 